\title{
DOES LIVELIHOOD VULNERABILITY INDEX JUSTIFY THE SOCIO-ECONOMIC STATUS OF MOUNTAINOUS COMMUNITY? A CASE STUDY OF POST-EARTHQUAKE ECOLOGICAL ADAPTATION OF BALAKOT POPULATION
}

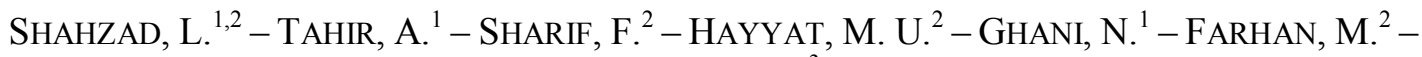 \\ DOGAR, S. S. ${ }^{3}$ \\ ${ }^{I}$ Environmental Science Department, Lahore College for Women University, Lahore, Pakistan \\ (e-mail/phone: arifatahir@gmail.com/+92-333-458-9622; nadiaghani2@yahoo.com/+92-315- \\ 422-4226) \\ ${ }^{2}$ Sustainable Development Study Center, Government College University, Lahore, Pakistan \\ (e-mail/phone: faizasharif@gcu.edu.pk/+92-331-447-1118; umerenv@yahoo.com/+92-321- \\ 403-2300; dr.muhammadfarhan@gcu.edu.pk/+92-321-412-2078) \\ ${ }^{3}$ National Agricultural Research Center (NARC), Islamabad, Pakistan \\ (e-mail/phone: salaar.saeed@gmail.com/+92-324-432-7567) \\ *Corresponding author \\ e-mail:lailashahzad@gcu.edu.pk; phone:+92-322-787-8517
}

(Received $1^{\text {st }}$ Feb 2019; accepted $29^{\text {th }}$ Mar 2019)

\begin{abstract}
Hindu Kush Himalayan is facing greater threat from socio-economic and climatic transitions. The current study has assessed livelihood vulnerability due to climatic variability of natural resource dependent mountainous communities. The northern side of Pakistan is expected to bear severe impacts due to its distinct topography, land use and climate change. Based on primary data collected from four villages complemented with secondary climatic data, livelihood vulnerability was evaluated through a composite indicator as livelihood vulnerability index (LVI) and LVI-IPCC. GIS mapping was carried out to assess land use change in the area. The comparative analysis of Tehsil Balakot showed that UC Balakot was more vulnerable with a LVI score of 0.41 than UC Kawai 0.35 . The results of in-depth analysis of differential vulnerability showed that households in UC Balakot had the low adaptive capacity and higher exposure to natural disasters. Developmental planners and policy makers should use such indices to assess root causes of vulnerability and specify community needs in policy making.
\end{abstract}

Keywords: climate change, natural disaster, differential vulnerability, adaptive capacity, land use change

\section{Introduction}

Rural people living on mountains are "vulnerable" to natural calamities and they need to adapt to climatic changes for their survival and better livelihood opportunities (Macchi, 2011; Gentle and Maraseni, 2012). The fifth assessment report of Intergovernmental Panel on Climate Change (IPCC) states that the climate change is one of the biggest challenges of the $21^{\text {st }}$ century that will bring about unexpected extreme events throughout the world ranging from polar regions to the tropics, islands, developed as well as developing countries (Hijioka et al., 2014). The Himalayas are of prime significance for Pakistan and as known to be the water towers. The ongoing climate change is showing negative impacts on the mountainous life by affecting water volumes, biodiversity, increasing natural hazards, ecosystem structure and function (Basharat et al., 2016; Sarwar et al., 2016). Sustainability of life in the mountainous 
regions is under extreme pressure due to higher dependence on natural resources and prevailing poverty (de Sherbinin, 2008).

Although, Pakistan has a very little contribution to the global climate change by greenhouse gases emissions but local climate change is becoming visible from the frequency and intensity of natural disasters affecting livelihoods of the rural communities. Pakistan faces a natural disaster almost every year and is now wellthought-out as one of the most vulnerable and highly effected country by changing climate in South Asia (IPCC, 2012; Shah et al., 2017). According to German-watch global climate risk index measured for a period of 1997 to 2016, Pakistan was on number seven among the world's vulnerable countries those faces most economic losses due to climatic changes (Ali and Erenstein, 2016; Abid et al., 2016). Factors that contribute to Pakistan's vulnerability profile are distinct geography, demographic trends, socioeconomic factors, and lack of adaptive capacity along with the perpetuating vicious cycle of poverty (Ainuddin et al., 2013; Elalem et al., 2015). Pakistan is among one of the countries with the least adaptive capacity due to the existence of a high level of poverty and lack of physical as well as financial resources (Chaudhury et al., 2016; Shah et al., 2018). Himalayan part of Pakistan is predominantly facing higher threats from changing climate and specific ecosystems are under significant pressure of loss in its services. In a recent study, people's perception of climate change has reported in terms of reduction in forest ecosystem services. In such marginalized communities, local ecosystems like forest and water provide multiple services, which will either diminished or reduced in quantity or quality (Shahzad et al., 2018). These ecosystems services are lifeline of local communities and in face of changing climate, livelihood and its related opportunities will be threatened (Shahzad et al., 2019).

IPCC defines vulnerability as a term which corresponds more to exposure and sensitivity of a system, place and people, and adaptation based on the wellbeing's resources (IPCC, 2001a, b, 2007). Vulnerability assessment is a study of conditions and process resulting from physical, social, economic and environmental factors that increase the susceptibility of a community to the impacts of hazards (Gerlitz et al., 2016). Different methods and indices have been explained through vulnerability assessment to examine the interactions between social and ecological systems, nonlinear feedbacks, spatial and temporal variation, human and their physical, social surroundings. Their application includes the measurement of trends in poverty, human development, food security, vulnerability and bio-diversity (Kotzee and Reyers, 2016). Vulnerability assessments can be conducted according to a range of approaches from descriptive to quantitative (Choe et al., 2017).

Livelihood Vulnerability Index (LVI) is used to analyze the vulnerability of domestic farming to climate change (Hahn et al., 2009). LVI is widely used in different parts of the world by many scientists to understand the specific vulnerability related to water, food, health and others sectors (Alam et al., 2017; Houng et al., 2018; Zhang et al., 2018). LVI is used to assess climate change vulnerability in coastal and inland communities of Mabote and Moma Districts of Mozambique, Africa (Hahn et al., 2009). It is widely used to understand climate based vulnerability of wetland-dependent communities (Shah et al., 2013) and rural riverine households (Alam et al., 2017) of Trinidad and Tobago islands and Bangladesh, respectively. Then LVI was used to indicate vulnerability in flood affected households of Bhagalpur Bihar, India (Madhuri et al., 2014). Gentle et al. (2014) assessed differential impacts of climate change based on distinct well beings of the communities in the Lamjung district of Nepal. The study 
coupled LVI with participatory well-beings ranking. In agriculture sector, LVI was used to analyze the impact of climate change on agro-livestock smallholders in Gandaki River Basin of Nepal (Panthi et al., 2015) and Northwest Vietnam (Houng et al., 2018) identified livelihood cycle and vulnerability in the rural riverine households of Bangladesh using LVI. However, most recently Zhang et al. (2018) examined the vulnerability of communities to climatic changes using LVI in the Gannan Plateau, which is one of most environmentally sensitive region of China. Such studies identified the root causes of vulnerability in different communities and helped locals in developing adaptations to identified vulnerable sectors. Gerlitz et al. (2016) used the multidimensional livelihood vulnerability index in the Hindu Kush Himalayan (HKH) region to examine livelihood vulnerability due to socio-economic and climatic changes.

However, there are very few reports available about the rural mountainous communities and no such study was undertaken to calculate the livelihood adaptations by using LVI after earthquake, 2005 in Balakot region. The current study has explored the livelihood vulnerability by accounting household adaptations and climate exposure of rural mountainous communities in Tehsil Balakot, Pakistan by using the Livelihood vulnerability index (LVI). The paper investigates potential factors of vulnerability based on community's exposure, sensitivity and adaptive capacity. It also aimed to assess land use changes in the region and its consequences on the livelihood of the rural people.

\section{Materials and methods}

\section{Study area}

Tehsil Balakot is a sub division of District Mansehra, Khyber Pukhton khawa (KPK) Province of Pakistan with an expected population of 22894 persons distributed in four main villages in almost 2857 households according to Mansehra District Plan Balakot (UNDP, 2007). It is geographically located at $34^{\circ} 33 \mathrm{~N}$ and $73^{\circ} 20 \mathrm{E}$ and encompasses an area of about $740 \mathrm{~km}^{2}$. The mountainous region has an average elevation of 500 to $5000 \mathrm{~m}$ asl with dense pine forest and River Kunhar flowing throughout (Somroo et al., 2012). Geologically this area comes under Hazara-Kashmir Syntax (HKS), which is circumscribed by the Main Boundary Thrust (MBT) (Sarwar et al., 2016). On the basis of seismological and structural data of 1904 to 2007, Bagh to Balakot has the most critical fault line of $120 \mathrm{~km}$ long (Mona, 2014). This makes the whole region highly susceptible to natural disasters, including earthquakes, landslides and avalanches (Baig, 2006; Kumar et al., 2006). The area was severely affected by the Kashmir Earthquake in 2005 which destroyed about 80 to $90 \%$ of the houses and resulted in huge death toll (Halvorson and Hamilton, 2007; Munir and Mirza, 2007). Loss of agricultural land had further enhanced their economic loses (Somroo et al., 2010). Rural people of Balakot are facing livelihood stress due to higher dependence on natural resources of the mountainous region which is already environmentally sensitive (Soomro et al., 2012). The rural community heavily relies on the forest and water resources of the area for subsistence livelihood. As a result, there is a higher threat of ecosystem changes and degradation which will amplify human vulnerabilities (Qasim et al., 2010). Forest cover has reduced due to the requirement of fuelwood and clearing the land to cultivate (UNDP Mansehra District 2007). Most of the people are cultivating seasonal vegetables on steep slopes of mountains. The region is a popular tourist destination of northern Pakistan which has many pros and cons for rural people. This condition has provided a rationale to assess that how the livelihood of the vulnerable rural people of Balakot will 


$$
-6608-
$$

be further influenced by the changing climate. The map of study area is shown in Figure 1.

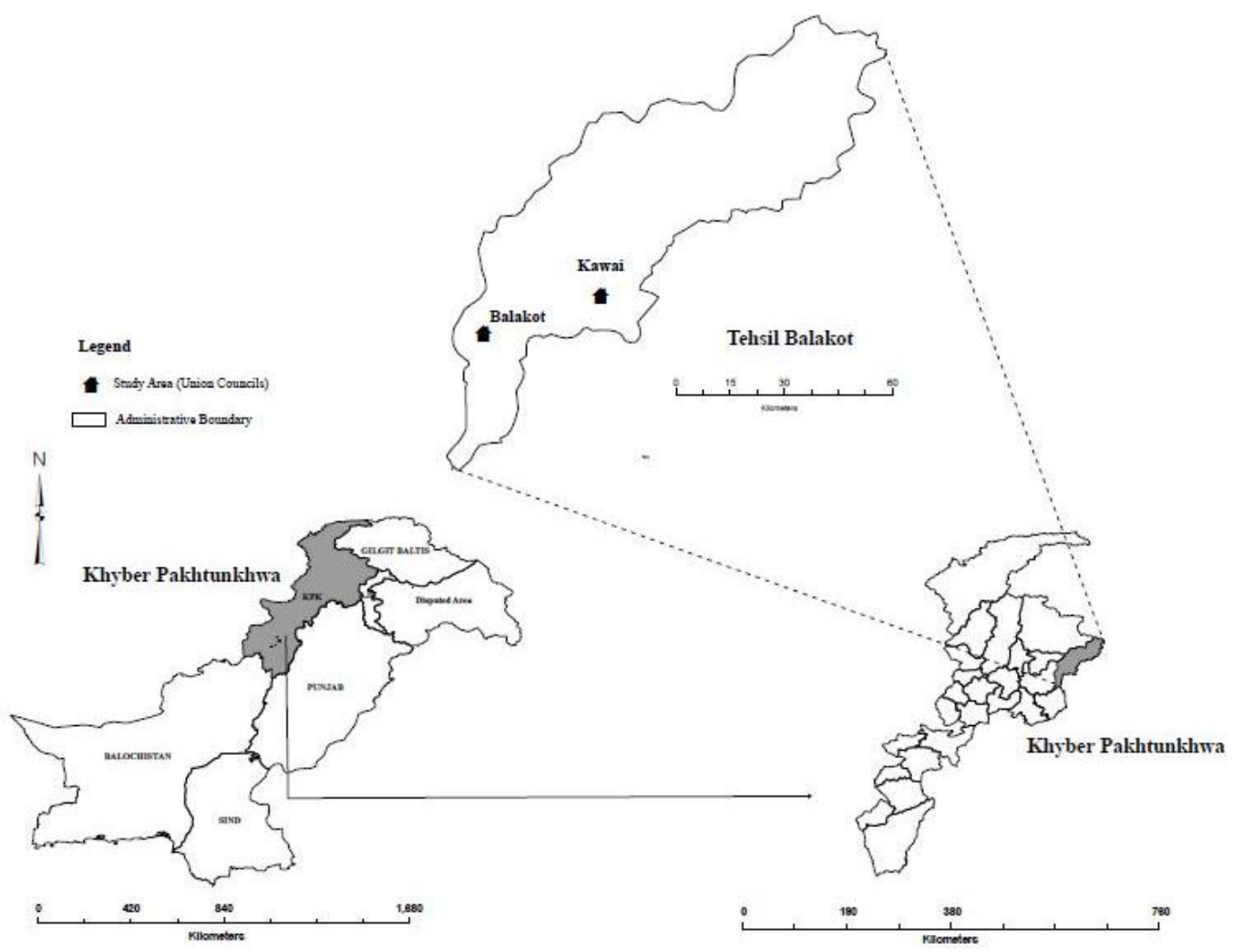

Figure 1. Map of Tehsil Balakot, District Mansehra, KPK Province-Pakistan indicating surveyed Union Council Balakot and Kawai

\section{Study population}

For the current study, households were the unit of observation to assess vulnerability based on the climatic and socio-ecological changes. The reason to choose such community is their dependence on the respective area's natural resources; so it becomes easy to assess their resilience or status of vulnerability (Shah et al., 2017). On the basis of these facts, two villages were surveyed from each UC to gather desired data. Taking $95 \%$ of confidence level, \pm 10 interval, a minimum sample size of 96 households was calculated. Keeping this in consideration, a total of 200 households were surveyed, where hundred 100 were chosen from each of two villages in Tehsil Balakot (Shahzad et al., 2018). The first site is Union council Balakot where most of households are close to river Kunhar and on the foothills. This area has sufficient human settlements living in higher vulnerability due to multi-hazards scenario of flood, earthquake and landslides. Second site Union Council Kawai was on the mid hill slopes near cultivated and forested lands, but far from water body. This area has usual landslides resultantly erosion and weathering are common phenomenon (Ullah et al., 2017).

\section{Methods used}

A mixed method approach was used to gather data based on interpretivist pragmatism which merges quantitative methods to qualitative methods dealing with 
individuals and their interactions in the society. Two extensive field visits were carried out, first in April 2017 and secondly in October 2017. In primary data collection, qualitative data was gathered through the participant's observations and focus group discussions (FGDs) $(\mathrm{N}=10)$. A field survey to get household level records $(\mathrm{n}=200)$ was also done which provided the quantitative data. Secondary data was taken from the union councils of Balakot and Kawai. Climate data consisting of temperatures and precipitation of Balakot and Kaghan stations was taken for the period of 1988 to 2017, accounting 30 years span. This data was provided by Meteorological Department Pakistan (PMD) and used to measure climatic variability and natural disaster's exposure. Along with LVI, land use maps were generated for the Tehsil to plot the change over the period of 20 years. For mapping land use change, remote sensed data of LANDSAT 5 and LANDSAT 7 were taken with path 150 and row 36. The spatial resolution of images used was $30 \mathrm{~m}$. Images of month of May 1990, 1995, 2010 and 2015 were taken for determining the variability. Images of year 2000 and 2005 were not accessible.

Details of each of method are explained under specific heading:

\section{Participants' observation}

In the study, participant's observation as a technique of qualitative research method was used to record the day to day activities and connection within communities (Fine, 2003; Stacy, 2004). This helped the in getting a better picture of community's culture and livelihood setting by observing how the people in the area live their life.

\section{Focus group discussions}

After acquiring the brief picture of local community, focus group discussions were carried out with the locals. A total of 10 groups were carried out, 5 in each village which facilitated in mapping the livelihood assets and threats due to changing climatic conditions. Male and female population was requested to be part of the discussions to have a representative approach in the study design.

\section{Household survey}

In addition to above methods, 200 households were visited door to door to get livelihood data using a questionnaire.

\section{Livelihood vulnerability index}

Two approaches were used to assess livelihood vulnerability: LVI and LVI-IPCC on the gathered data. The livelihood vulnerability index was established on the descriptive information generated by the field survey which was based on set of indicators. These sub components were coupled into eight major components and three factors of vulnerability in both UCs (Table Al in the Appendix).

Approach I - LVI: The eight major components of vulnerability were inquired using survey questions as livelihood indicators. The eight components calculated at household level were socio-demographic profile (SDP), livelihood strategies (LS), social network $(\mathrm{SN})$, health $(\mathrm{H})$, food $(\mathrm{F})$, water $(\mathrm{W})$, natural disaster $(\mathrm{ND})$ and climatic variability $(\mathrm{CV})$. Each of these major components had different questions; seven indicator questions were placed for LS, six for $\mathrm{H}$, five for F, four for ND, SN, W, SDP and three 
questions for $\mathrm{CV}$. Therefore, a total of 37 indicator questions were described in column three of Table A1. Each major component of LVI was measured through four steps: (1) Compute the questionnaire data of sub-component and transform into percentage, ratio and index. (2) Unit standardization of each sub-component (Sullivan et al., 2002) (3) Calculate the average of each standardized score to get the final value for each main component. (4) Weighed the averages of all major components to obtain the LVI value. This procedure confirms the equal contribution of main components to generate the overall LVI. The scale of LVI calculated from this approach ranges from 0 (minimum) to 0.5 (maximum) as described by Hahn et al. (2009).

The formula is shown as Equation 1:

$$
\operatorname{Index} x_{s}=\frac{s_{S}-s_{\min }}{s_{\max }-s_{\min }}
$$

where $s_{S}=$ original sub-component for each of the site,

$s_{\min }=$ minimum value for each sub-component,

$s_{\max }=$ maximum value for each sub-component.

After obtaining values of sub-components, average of each sub-component was calculated using Equation 2:

$$
M_{s}=\frac{E_{i=1}^{\mathrm{n} i n d e n} s_{S^{i}}}{n}
$$

where $M_{S}=$ one of the eight major components for study site,

index $s_{s^{i}}=$ subcomponent, $n=$ number of subcomponents in each major component.

The above values were calculated for each of the eight components and LVI was calculated using the formula mentioned as Equation 3 and elaborated in Equation 4:

$$
L V I_{s}=\sum_{i=1}^{g} W_{M^{i M s}} / \sum_{i=1}^{8} W_{M i}
$$

Equation 3 can also be elaborated as:

$$
L V I_{S}=\frac{W_{S D P} S D P_{S}+w_{L S}+L S_{S}+W_{S N} S N_{S}+w_{H} H_{S}+W_{F} F_{S}+W_{W} W_{S}+w_{C V} W_{S}+w_{N D} W_{S}}{W_{S D F}+w_{L S}+W_{S W}+W_{H}+W_{F}+w_{W}+W_{C V}+W_{W D}} \text { (Eq.4) }
$$

where SDP represents socio-demographic profile for each UC, LS is livelihood strategies, $\mathrm{SN}$ is social networking, $\mathrm{H}$ is for health, $\mathrm{W}$ for water, $\mathrm{CV}$ is climatic variability and ND is natural disasters.

Approach II - LVI-IPCC: Livelihood vulnerability based on the IPCC definition was also quantified which is the measurement of exposure, sensitivity and adaptive capacity (represented in Equation 5). According to the framework, exposure represented by "e" is ranking of exposure to any natural hazards/disaster which rural community has faced in last 5 years. Whereas "s" is for sensitivity and "a" is for adaptive capacity measured for household. Adaptive capacity is based on the scores of socio-demographic, livelihood strategies and social networks. Exposure is grouped in natural disasters and climatic variability. However Sensitivity is calculated by taking the scores of health, food and water. The LVI-IPCC scale ranges from -1 (minimum) to +1 (maximum). 


$$
L V I-I P C C_{s}=\left(e_{s}+a_{s}\right) \times s_{s}
$$

\section{Land-use change mapping}

To obtain information of land use changes in Tehsil Balakot, remote sensing data was interpreted to produce maps of these years; 1990, 1995, 2010 and 2015. Landsat 7 Enhanced thematic Mapper Plus (ETM+) and Landsat 5 Thematic Mapper (TM) were used from United State Geological Survey (USGS). The interpretation was done using Erdas imagine software through supervised maximum likelihood classification, also used Google Earth Engine and ArcGIS for further processing on classified rasters. Final output maps were designed by using ArcGIS 10.5. Six major classes of land use were described and shown in Table 4. Changes in time periods were calculated for each land use class between a final year V2 and an initial year, V1 as shown in Equation 6.

$$
\text { Percentage Change }=\left(V_{1}-V_{2} \mid V_{1}\right) \times 100
$$

\section{Results}

\section{Livelihood vulnerability index in Tehsil Balakot}

Household level of vulnerability was calculated at both study sites (Table A1; Fig. 2). It was found that both areas were vulnerable to the changing climate, however; LVI values were higher for UC Balakot (0.43) than UC Kawai (0.33). This indicated that riverbank communities were more vulnerable than people living on slopes. The major differences in the sub-component scores were of natural disasters accounting 0.52 for Kawai and 0.78 for Balakot. Balakot community was exposed to higher hazards due to floods and landslides. Climatic variability was similar in both study areas due to having similar meteorological data of Tehsil Balakot. However, health status of the respondents was not much different in both UCs having a major component score of 0.45 (Balakot) and 0.46 (Kawai). Both areas had no household gas supply for cooking, therefore using woods, leaf litter and other biomass fuels to cook and heat the homes. In terms of food availability, households had less storage of seed in Balakot (0.07) which is an adaptation in time of crises. Many households had no crop diversity; they were sowing same crops over time which indicates lower adaptations in changing time. The maximum score of food was shown in Kawai (0.34) relative to Balakot (0.24). Most of the households had higher dependency on natural water sources in Kawai (0.66) rather than Balakot (0.42). In assessing the status of water accessibility in households, Balakot had higher LVI value (0.49) as compared to Kawai (0.45). Socio-demographically Balakot had shown poor statistics with an index value of 0.4 as compared to Kawai (0.28). In UC Balakot, villages are highly vulnerable, due to low income and education having an average score of LVI 0.41 .

After calculating and summarizing LVI for both union councils, a spider diagram (Fig. 2a) was developed to indicate value of major components and resulting vulnerabilities. In both study areas, exposure to natural disasters had comparatively higher score than other components.

\section{Calculating LVI-IPCC}

The three major components of vulnerability were calculated from eight major components. Adaptive capacity index consist of socio demographic profile, livelihood 
strategies and social networks in a community. Sensitivity index is composed of health, food and water related issues. In exposure index only natural disasters and climate variability is considered. For LVI-IPCC approach, +1 indicates most vulnerable and -1 is for least vulnerable. The contributing factor value for IPCC-LVI approach is 0 for low contributing factor value and 0.6 for high contributing factor value. Results of LVIIPCC have suggested that the community of Tehsil Balakot has higher exposure level. UC Kawai has comparatively low exposure to natural hazards and climatic variability than UC Balakot. Overall both communities had shown very low adaptive capacity, therefore highly vulnerable to environmental and social changes in the study area. There are three categories to recognize the vulnerability status as shown in Table 1.
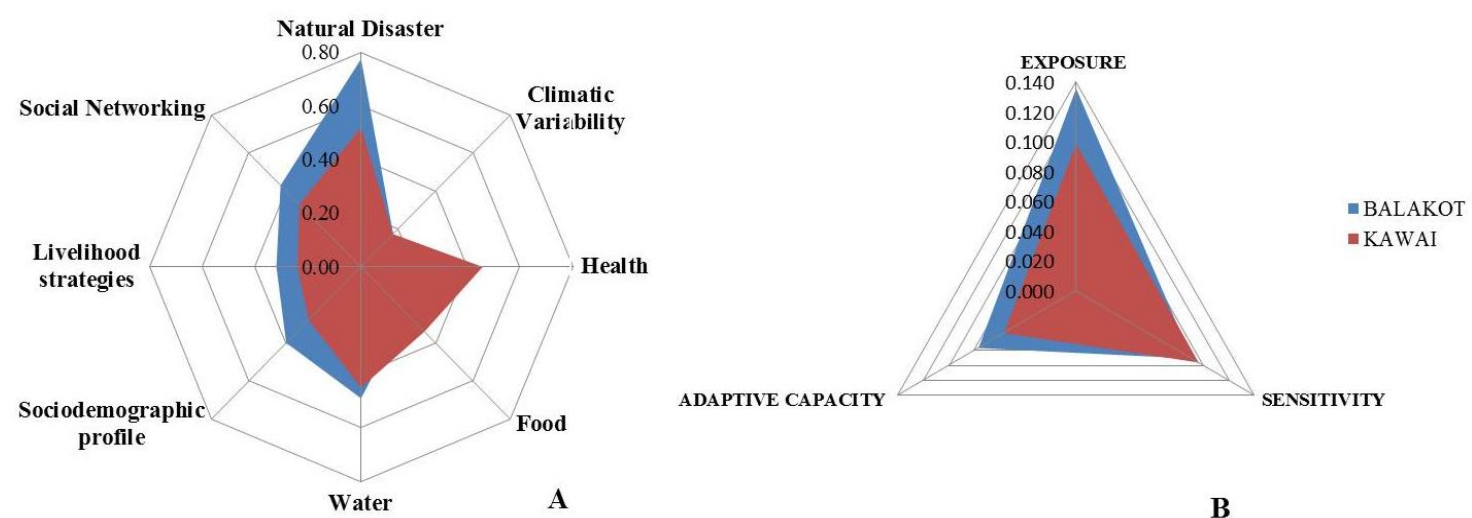

Figure 2. a Spider diagram indicating major component scores of LVI. $\boldsymbol{b}$ Vulnerability triangular sketch showing scores of LVI-IPCC in Tehsil Balakot

Table 1. Status of vulnerability based on IPCC-LVI ( $a=$ adaptive capacity; $e=$ exposure and $s=$ sensitivity)

\begin{tabular}{c|c|c}
\hline LVI-IPCC categories & UC Balakot & UC Kawai \\
\hline $\begin{array}{c}\text { Adaptive Capacity }>\text { (Exposure }+ \text { Sensitivity })= \\
\text { Less Vulnerable }\end{array}$ & $\mathrm{a}<(\mathrm{e}+\mathrm{s})$ & $\mathrm{a}<(\mathrm{e}+\mathrm{s})$ \\
\hline $\begin{array}{c}\text { Adaptive Capacity }=(\text { Exposure }+ \text { Sensitivity })= \\
\text { Moderately Vulnerable }\end{array}$ & $0.077<(0.091+0.136)$ & $0.057<(0.096+0.099)$ \\
\hline $\begin{array}{c}\text { Adaptive Capacity }<\text { (Exposure }+ \text { Sensitivity })= \\
\text { Highly Vulnerable }\end{array}$ & $0.077<0.227$ & $0.057<0.195$ \\
\hline
\end{tabular}

Vulnerability triangular diagram was developed from the scores of LVI-IPCC (Fig. 2b). It ranges from 0 to 0.14 which showed that UC Kawai was more sensitive to climatic and livelihood changes with less adaptive capacities however UC Balakot has higher level of exposure. An in-depth analysis showed Balakot has geographically more prone to natural disasters and as a result community has learnt some adaptations due to facing losses. An overall impact analysis indicated (Table 2) that low adaptive capacity was due to poor social status coupled with low social support. Sensitivity was influenced by the primary factors of water and health related issues whereas exposure was significantly due to presence of nature hazards already established in study area. 
Table 2. LVI and LVI-IPCC based on contributing factors and vulnerability scores for Tehsil Balakot

\begin{tabular}{|c|c|c|c|c|c|c|}
\hline \multirow{2}{*}{$\begin{array}{c}\text { Contributing } \\
\text { factors }\end{array}$} & \multirow[b]{2}{*}{ Major components } & \multirow{2}{*}{$\begin{array}{l}\text { No. of sub } \\
\text { components }\end{array}$} & \multicolumn{2}{|c|}{ Balakot } & \multicolumn{2}{|c|}{ Kawai } \\
\hline & & & $\begin{array}{c}\text { Major components } \\
\text { values }\end{array}$ & $\begin{array}{l}\text { Contributing } \\
\text { factor values }\end{array}$ & $\begin{array}{c}\text { Major components } \\
\text { values }\end{array}$ & $\begin{array}{l}\text { Contributing } \\
\text { factor values }\end{array}$ \\
\hline \multirow{3}{*}{$\begin{array}{l}\text { Adaptive } \\
\text { capacity }\end{array}$} & Social demographic & 4 & 0.40 & \multirow{3}{*}{0.077} & 0.28 & \multirow{3}{*}{0.057} \\
\hline & Livelihood strategies & 7 & 0.32 & & 0.24 & \\
\hline & Social networks & 4 & 0.43 & & 0.33 & \\
\hline \multirow{3}{*}{ Sensitivity } & Health issues & 6 & 0.45 & \multirow{3}{*}{0.091} & 0.46 & \multirow{3}{*}{0.096} \\
\hline & Food related & 5 & 0.24 & & 0.34 & \\
\hline & Water issues & 4 & 0.49 & & 0.45 & \\
\hline \multirow{2}{*}{ Exposure } & Natural disasters & 4 & 0.78 & \multirow{2}{*}{0.136} & 0.52 & \multirow{2}{*}{0.099} \\
\hline & Climatic variability & 3 & 0.172 & & 0.172 & \\
\hline \multicolumn{3}{|c|}{ LVI (0 minimum to 0.5 maximum) } & \multicolumn{2}{|l|}{0.41} & \multicolumn{2}{|c|}{0.35} \\
\hline \multicolumn{3}{|c|}{ LVI-IPCC ( -1 minimum to +1 maximum) } & \multicolumn{2}{|c|}{0.0054} & \multicolumn{2}{|c|}{0.0040} \\
\hline
\end{tabular}

\section{Mapping land use change and its effect on livelihood}

Tehsil Balakot has been affected by changing in its land use scenarios which was shared by most of the households during in-depth interview. Many were of view that availability of fresh and clean water has reduced along with reduced forest cover. Results revealed (Table 3; Fig. 3) that there was significantly increase in the settlements in year 2015 than 1990. A drop in population from 1995 to 2010 was due to a higher death toll in earthquake of 2005 . It was documented that $90 \%$ households suffered two or more than two deaths in this disaster (Qasim et al., 2010). Forest cover was significantly reduced from 1990s to 1995 and 2010. An increase in forest cover in 2015 was due to a provincial program namely Billion Tree Tsunami Project (BTTP) which was an afforestation effort in line with international Bonn Challenge (WWF, 2017.). Pakistan promised to restore six million hectares of degraded forest land by year 2020 according to this commitment. Another greater change reported by locals in their FGD was conversion of forest land into cultivation. Vegetation in the map and tabular data represents all type of cultivation carried out in the study area. Tehsil Balakot has higher production of maize and wheat, rice production comes in third place with many seasonal vegetables. Agriculture has been a substantial livelihood strategy in this region. It can be seen from the land use mapping that agriculture has got momentous increase which will affect climate and livelihood in positive and negative too. Barren land is the region has increased also which was majorly due to drying of river body. On the hand, ice and snow has reduced too which was supported by aged people during FGD that glacier' melting is amplified in the region coupled with flooding and resulting landslides. Water bodies including rivers, springs and lakes have significantly reduced in its volume affecting agriculture, fishing, livestock rearing and related livelihood activities.

\section{Discussion}

The outcome of the study in Tehsil Balakot revealed that all four villages in both UCs were highly vulnerable based on LVI and LVI-IPCC approaches. In the first glance, the study suggests that there was a less difference in the vulnerability scenario of two areas. However a closer look reveals that there were much more differences. 


$$
-6614-
$$
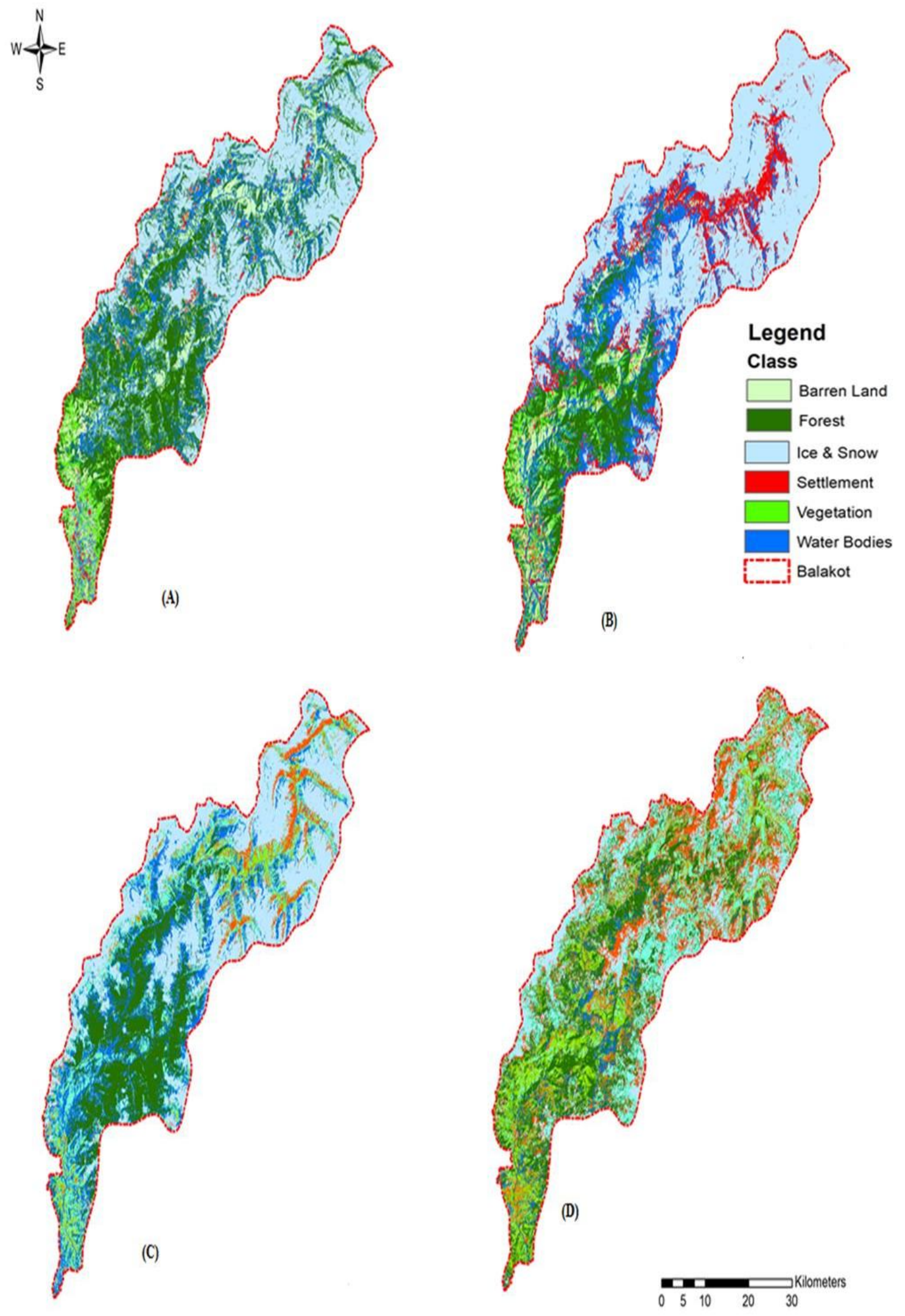

Figure 3. Land use changes reported in Tehsil Balakot for the period of 1990 (a), 1995 (b), 2010 (c) and 2015 (d) 
Table 3. Land-use classes in Tehsil Balakot and change in land use reported from 1990 to 2015

\begin{tabular}{|c|c|c|c|c|c|c|c|c|c|}
\hline \multirow{2}{*}{$\begin{array}{l}\text { Land use } \\
\text { classes }\end{array}$} & \multirow[b]{2}{*}{ Description in the study area } & \multicolumn{4}{|c|}{ Land use (\% response) } & \multicolumn{4}{|c|}{ Percentage change } \\
\hline & & 1990 & 1995 & 2010 & 2015 & 1990-1995 & $1995-2010$ & 2010-2015 & $\begin{array}{c}\text { Overall } \\
1990-2015\end{array}$ \\
\hline Forest & $\begin{array}{c}\text { All type of forests where trees } \\
\text { growing in patches and } \\
\text { canopies }\end{array}$ & 30.05 & 12.56 & 19.24 & 24.67 & -58.81 & +53.34 & +28.08 & -17.90 \\
\hline Settlement & $\begin{array}{l}\text { Continuous and discontinuous } \\
\text { buildings where people living }\end{array}$ & 1.64 & 10.45 & 5.67 & 18.26 & +537.19 & -45.74 & +222.04 & +1013.41 \\
\hline $\begin{array}{l}\text { Vegetation } \\
\text { (agriculture) }\end{array}$ & $\begin{array}{c}\text { Regularly ploughed land for } \\
\text { irrigated crops or growing rain- } \\
\text { fed crops }\end{array}$ & 4.54 & 5.75 & 6.08 & 18.26 & +26.65 & +5.73 & +200.32 & +302.20 \\
\hline Barren land & $\begin{array}{c}\text { Land with eroded soil and top } \\
\text { surface soil with no vegetation } \\
\text { and no settlements }\end{array}$ & 14.98 & 5.71 & 16.3 & 21.07 & -61.88 & +185.46 & +29.26 & +40.65 \\
\hline Ice \& snow & $\begin{array}{c}\text { Area covered with ice and snow } \\
\text { continuously or for a part of } \\
\text { time in a year }\end{array}$ & 31.82 & 46.55 & 32.54 & 16.91 & +46.29 & -30.09 & -48.03 & -46.85 \\
\hline Water bodies & $\begin{array}{l}\text { Water courses like rivers and } \\
\text { streams, lakes and ponds }\end{array}$ & 16.97 & 19.15 & 20.19 & 5.09 & +12.84 & +5.43 & -74.78 & -70.05 \\
\hline
\end{tabular}

+ indicates increase in certain activity whereas a minus (-) indicates decrease

\section{Livelihood vulnerability status in Tehsil Balakot}

The overall analysis has shown that UC Balakot had higher dependence ratio per household with more female headed households than UC Kawai which make their low socio-demographic profile. In addition to this, UC Balakot has low education and less income in most of the households. Most households had shown less or no livelihood diversification that showed their dependence on single source of income which was onfarm activities in most villages. Poverty and vulnerability are thoroughly linked; poor households are characterized as more vulnerable (Isabel and Buchenrieder, 2010). Many studies have reported similar findings (Adu et al., 2018; Sujakhu et al., 2018; Huong et al., 2018) where poverty is leading to vulnerability in most parts of the world. In addition, literature has strongly supported the idea of livelihood diversification leads to community resilience (Rahut et al., 2014; Gautam and Andersen, 2016). Most of the households involved in farming had less or no crop diversification as an adaptation technique. UC Balakot had many households involved in nature-based tourism; ranging from running huts for tourists to selling day to day items. This area is a popular tourist destination which has resulted in unstable construction of motels and huts on the riverbank as well as hill slopes. Social networking is taken as an adaptation strategy in rural livelihood (Sujakhu et al., 2018) as it enhanced community linkages and a support system. The livelihood was under stress due to low adaptive capacity which has indicated the people had low socio-demographic profiles with poor social networking. In addition to this, people had less livelihood adaptations in both areas. Similar finding were reported by an earlier study done by Gerlitz et al. (2016) in Hindu Kush Himalayan $(\mathrm{HKH})$ where the community was identified more vulnerable due to low adaptive capacity and higher exposure to climatic and socio-economic factors. Surveys in this mountainous region has shown that the majority of households observed changes in their environment, precipitation and monthly temperatures; further it was reported that these changes will be adverse in next few years (Colom and Pradhan, 2013; Zaheer and Colom, 2013; Gambhir and Kumar, 2013; Tse-ring et al., 2010). In a similar study 
conducted by Wang et al. (2016) uneven seasonal precipitation distribution was also reported in this region which wills undesirably effects the agriculture and livestock production. Literature reported less rainfall and extreme weather array in this region of Hindukush Himalayan which has provided environmental and socio-economic shocks to the livelihood of marginalized communities (Akhtar et al., 2008; Gerlitz et al., 2015; Alam, 2017). Reduction in water springs and change in water quality was reported by the people during their focus group discussion. This was severely affecting agriculture productivity as well as food security of rural farmers.

However the regional Himalayan are experiencing similar conditions but different sensitivities also due to different types of income, education household characteristics, and way of livelihood diversification. For instance, in Gannan Plateau, located in the east of the Qinghai-Tibet Plateau, which is highly environmental sensitive region of china showed higher exposure scenarios than sensitivity (Zhang et al., 2018). In another in-depth study, comparative analysis among, India, Nepal and Pakistan; multidimensional vulnerability index showed higher exposure to changing environmental and socio-economic status. Access to basic faculties was highlighted as an additional burden on population of this region (Gerlitz et al., 2016). In riverbank erosion-affected riparian regions of Bnagladesh (Chauhali and Nagarpur), LVI accounted food, water and health issues causing higher vulnerability. Poverty is reasoned as main source of higher exposure to extreme conditions (Alam et al., 2017). However In Ghana Africa, it was reported that livelihood based on climate regulated water resources was highly vulnerable due to low adaptive capacity then exposure and sensitivities. Most municipalities in the Brong-Ahafo region were involved in maize farming and it was indicated that change in water availability was considered as main livelihood threat (Adu et al., 2018). In another study conducted by Jianchu et al. (2007) in context of melting Himalayan showed that mountain people have lived with extreme conditions but more effecting is the pace and magnitude of changing climate. And other contribution in higher community's vulnerability is lack of scientific investigation. Therefore more and more scientific studies coupled with indigenous knowledge are needed to make poor locals of Himalayan more resilient.

\section{Land use changes and livelihood analysis}

Field survey with local people and remote sensed data has established the fact that land use change has influenced the socio-economic and livelihood conditions in the region. The data of last five years has seen vivacious effects on forest, agriculture and water resources. In HKH region the environmental changes were reported earlier in 1970s; which included higher deforestation, burgeoning population growth, glacier melting, soil erosion and low lying flooding (Sterling, 1976; World Bank, 1979; Karan and Iijima, 1985; Schickhoff, 1995). Hence with poor evidences and empirical studies, an in-depth livelihood analysis was not possible. The current study therefore provided ground data to support the limited works. The land use change data has long-established fact that agriculture and water bodies were significantly reduced whereas settlements due to growing population had amplified (Khurshid et al., 2016). Higher population will subsequently put higher pressure on natural resources which in turn elevates poverty. This vicious cycle was reported already in Bangladesh, India, Nepal and other neighboring countries (Gentle et al., 2014; Aryal et al., 2016). In the study area, settlements have increased 10-folds since 1990; after 2010 a rapid increase in population was seen which was may be due to higher tourism demand linked to this 
area. Better road infrastructure was one of facilitation which has developed access to off-routes. Many people travel to this part of country around the year, which has resulted in environmental degradation. Water resources of $\mathrm{HKH}$ are critical for Pakistan as an agricultural economy, the water bodies are reduced and snow and ice are melting; this will have cascading effects. HKH are known as water towers for Pakistan and drying water bodies will threaten country's socioeconomic growth as well. Further, increase in global warming and climate change will likely effect the hydrological cycle.

Agriculture productivity and livelihood of rural mountainous communities heavily depend upon water availability (Sullivan, 2002; Khattak et al., 2011; Yang and Yang, 2014; Aryal et al., 2018). In current scenario, local people are converting more and more forest land into cultivation but in near future with less water available, food insecurity will result. The drying water bodies were extending barren lands in the region (Jainachu et al., 2007; Mahmood et al., 2016). Reduction in forest size and cover was already described by the locals for higher need of fuel wood (Khan, 1970; Gentle and Maraseni, 2012; Aryal et al., 2017). These forests are lifeline to rural community; rapid deforestation will expose local people to more natural hazards and warming also. Many plants and animal species have already moved from these temperate zones as reported by local people during the field surveys. Tehsil Balakot is a famous tourism area in northern Pakistan; which will be severely affected due to loss of forest and water bodies. These land use changes in the HKH region will have long term effects on the livelihood of rural people.

In terms of changes mapped over Himalayan region, many similar studies showed change in land use and related phenomenon. Sharma et al. (2007) carried out land use change mapping in western Himalayan, State of Himachal Pradesh, India indicating two-folded increase in population growth and reduced forest cover. Another change was in form of introduction of profitable crops other than wheat and maize in the region. In a recent study in Garhwal Himalayan region (Batar et al., 2017), vulnerability to life of locals due to higher deforestation and forest fragmentation was reported. The major land-use change was accounted to fuel-wood consumption and other anthropogenic activities. The study has described fast decline in the forest cover which will be higher threat to locals in form of natural hazards. However a study conducted in Himalayan region of Nepal showed transitions in land use change from forest to agriculture and shrubs and agriculture to forested land (Chapagain et al., 2018). It was also reported that beginning of community forest was considered a main driver behind the increase in forest cover in the region, followed by shortage of labor and development of infrastructure. Another study in the landscape of Abaya-Chamo Basin (ACB), southern Ethiopia, the main changes observed were rapid reduction in shrubland and grassland (33.13\%), and massive increase in arable land (Yohannes et al., 2018). Rapid population growth was also seen in the region resulting in higher pressure on natural resources.

Overall the higher vulnerability in the different parts of world was due to risk factors related to poverty, poor basic life facilities and low adaptive capacity. Most of the populations had been exposed to climate related threats and thus have vulnerable livelihoods. On the other hand, land use change poses additional burden in all regions of world because of growing population, reduced forest cover and increased arable land (Gentle et al., 2014; Gerlitz et al., 2016; Yohannes et al., 2018; Adu et al., 2018). 


$$
-6618 \text { - }
$$

\section{Conclusion}

People in Tehsil Balakot are vulnerable due to their poor social and environmental conditions. The current study highlighted vulnerability at a household level using acknowledged method. Surveys in this region showed that the majority of households had already observed the change in environment and climatic conditions. Local people had higher exposure to changes but low adaptive capacity to cope it. This condition has made them highly susceptible to bear lose. Land use analysis has also indicated alteration in agriculture and water availability which will negatively affect the rural livelihood. There are few empirical studies using indices to identify root causes of vulnerability across different sectors. The study offers an assessment approach which can be replicated for regional and national level studies to know the causes of susceptibility to natural disasters. Realistic studies are needed to highlight exposure, sensitive and adaptive capacity of rural people to enhance their resilience and adaptations to change. This can help decision makers and planners to address the challenge which is biggest in $21^{\text {st }}$ century.

\section{REFERENCES}

[1] Abid, M., Schilling, J., Scheffran, J., Zulfiqar, F. (2016): Climate change vulnerability, adaptation and risk perceptions at farm level in Punjab, Pakistan. - Science of the Total Environment 547: 447-460.

[2] Adu, D. T., Kuwomu, J. K. M., Somuah, H. A., Sasaki, N. (2018): Application of livelihood vulnerability index in assessing smallholder maize farming households' vulnerability to climate change in Brong-Ahafo region of Ghana. - Kasetsart Journal of Social Sciences 39: 22-32.

[3] Ainuddin, S., Aldrich, D. P., Routray, J. K., Ainuddin, S., Achkazai, A. (2013): The need for local involvement: decentralization of disaster management institutions in Baluchistan, Pakistan. - International Journal of Disaster Risk Reduction 6: 50-58.

[4] Akhtar, M., Ahmad, N., Booij, M. J. (2008): The impact of climate change on the water resources of Hindukush-Karakorum-Himalaya region under different glacier coverage scenarios. - Journal of Hydrology 355: 148-163.

[5] Alam, G. M. M. (2017): Livelihood cycle and vulnerability of rural households to climate change and hazards in Bangladesh. - Environmental Management 59: 777-791.

[6] Ali, A., Erenstein, O. (2016): Assessing farmer use of climate change adaptation practices and impacts on food security and poverty in Pakistan. - Climate Risk Management 16: 183-194.

[7] Aryal, S., Cockfield, G., Maraseni, T. N. (2016): Perceived changes in climatic variables and impacts on the transhumance system in the Himalayas. - Climate and Development 8(5): 1-12.

[8] Aryal, S., Cockfield, G., Maraseni, T. N. (2017): Globalisation and traditional socialecological systems: understanding impacts of tourism and labour migration to the transhumance systems in the Himalayas. - Environmental Development. http://dx.doi.org/10.1016.

[9] Aryal, S., Panthi, J., Dhakal, Y. R., Gaire, N. P., Karki, K., Joshi, N. R. (2018): Historically evolved practices of the Himalayan transhumant pastoralists and their implications for climate change adaptation. - International Journal of Global Warming 14(3): 356-371.

[10] Baig, M. S. (2006): Active Faulting and Earthquake Deformation in Hazara-Kashmir Syntaxis, Azad Kashmir, Northwest Himalaya. - In: Kausar, A. B., Karim, T., Kham, T. (eds.) International Conference on 8 October 2005 Earthquake in Pakistan: Its 
Implications and Hazard Mitigation. January 18-19, 2006, Islamabad, Pakistan, Extended Abstract, pp. 27-28.

[11] Basharat, M., Shah, H. R., Arab, N. H. (2016): Landslide susceptibility mapping using GIS and weighted overlay method: a case study from NW Himalayas. - Pakistan Journal of Geosciences 9: 292.

[12] Batar, A. K., Watanabe, T. Kumar, A. (2017): Assessment of land-use/land-cover change and forest fragmentation in the Garhwal Himalayan region of India. - Environments 4(34). http://doi:10.3390/environments4020034.

[13] Chaudhury, A. S., Ventresca, M. J., Thornton, T. F., Helfgott, A., Sova, C., Baral, P., Ligthart, J. (2016): Emerging meta-organisations and adaptation to global climate change: Evidence from implementing adaptation in Nepal, Pakistan and Ghana. - Global Environmental Change 38: 243-257.

[14] Chapagain, P. S., Rai, M. K., Paudel, B. (2018): Land use land cover change and its pathways in Sidin VDC, Panchthar district, Nepal. - The Geographical Journal of Nepal 11: 77-94.

[15] Choe, H., Thorne, J. H., Hijmans, R., Kim, J., Kwon, H., Seo, C. (2017): Meta $\square$ corridor solutions for climate $\square$ vulnerable plant species groups in South Korea. - Journal of Applied Ecology 54(6): 1742-1754.

[16] Colom, A., Pradhan, S. (2013): Nepal - How the people of Nepal live with Climate Change and What Communication Can Do. - BBC Media Action, London, UK.

[17] de Sherbinin, A., VanWey, L. K., McSweeney, K., Aggarwal, R., Barbieri, A., Henry, S., Hunter, L. M., Twine, W., Walker, R. (2008): Rural household demographics, livelihoods and the environment. - Global Environmental Change 18(1): 38-53.

[18] Elalem, S., Pal, I. (2015): Mapping the vulnerability hotspots over Hindu-Kush Himalaya region to flooding disasters. - Weather and Climate Extremes 8: 46-58.

[19] Fine, G. A. (2003): Towards a peopled ethnography developing theory from group life. Ethnography 4(1): 41-60.

[20] Gambhir, V., Kumar, P. (2013): India - How The People of India Live with Climate Change and What Communication Can Do. - BBC Media Action, London, UK.

[21] Gautam, Y., Andersen, P. (2016): Rural livelihood diversification and household wellbeing: Insights from Humla, Nepal. - Journal of Rural Studies 44: 239-249.

[22] Gentle, P., Maraseni, T. N. (2012): Climate change, poverty and livelihoods: adaptation practices by rural mountain communities in Nepal. - Environmental Science and Policy 21: 24-34.

[23] Gentle, P., Thwaites, R., Race, D., Alexander, K. (2014): Differential impacts of climate change on communities in the middle hills region of Nepal. - Natural Hazards. $\mathrm{http} / /$ doi.10.1007/s11069-014-1218-0.

[24] Gerlitz, J. Y., Banerjee, S., Brooks, N., Hunzai, K., Macchi, M. (2015): Vulnerability and Adaptive Capacity Assessment: An Approach to Measure Vulnerability and Adaptation to Climate Change. - In: Leal Filho, W. (ed.) Handbook of Climate Change Adaptation. Springer, Berlin/Heidelberg, pp. 151-176.

[25] Gerlitz, J. Y., Macchi, M., Brooks, N., Pandey, R., Banerjee, S., Jha, S. K. (2016): The multidimensional livelihood vulnerability index - an instrument to measure livelihood vulnerability to change in the Hindu Kush Himalayas. - Climate and Development 9(2): 124-140.

[26] Hahn, M. B., Riederer, A. M., Foster, S. O. (2009): the livelihood vulnerability index: a pragmatic approach to assessing risks from climate variability and change - a case study in Mozambique. - Global Environmental Change 19(1): 74-88.

[27] Halvorson, S. J., Hamilton, J. P. (2007): Vulnerability and the erosion of seismic culture in mountainous Central Asia. - Mountain Research and Development 27(4): 322-330.

[28] Hijioka, Y., Lin, E., Pereira, J. J., Corlett, R. T., Cui, X., Insarov, G. E., Lasco, R. D., Lindgren, E., Surjan, A. (2014): Asia. - In: Climate Change 2014: Impacts, Adaptation, and Vulnerability. Part B: Regional Aspects. Contribution of Working Group II to the 
Fifth Assessment Report of the Intergovernmental Panel on Climate Change. Cambridge University Press, Cambridge, UK and New York, pp. 1327-1370.

[29] Huong, N. T. L., Shunbo, Y., Shah, F. (2018): Assessing household livelihood vulnerability to climate change: the case of Northwest Vietnam. - Human and Ecological Risk Assessment: An International Journal. https://doi.org/10.1080/10807039.2018.1460801.

[30] IPCC (2001a): Climate Change 2001. The Scientific Basis. Intergovernmental Panel on Climate Change. - Cambridge University Press, Cambridge, UK.

[31] IPCC (2001b): Climate change 2001. Impacts, Adaptation and Vulnerability. Intergovernmental Panel on Climate Change. - Cambridge University Press, Cambridge, UK.

[32] IPCC (2007): Climate Change 2007. The Physical Science Basis. Contribution of Working Group I to the Fourth Assessment Report of the Intergovernmental Panel on Climate Change. - Cambridge University Press, Cambridge, UK.

[33] IPCC (2012): Managing the Risks of Extreme Events and Disasters to Advance Climate Change Adaptation. A Special Report of Working Groups I and II of the Intergovernmental Panel on Climate Change. - Cambridge University Press, Cambridge, UK, and New York.

[34] Isabel, F., Buchenrieder, G. (2010): Risk management of vulnerable rural households in southeast Asia. - 9th European IFSA Symposium, 4 $\square 7$ July 2010, Vienna (Austria).

[35] Jianchu, X., Shrestha, A., Vaidya, R., Eriksson, M. Hewitt, K. (2007): The Melting Himalayas. Regional Challenges and Local Impacts of Climate Change on Mountain Ecosystems and Livelihoods. - Technical Paper. International Centre for International Mountain Development (ICIMOD) Kathmandu, Nepal.

[36] Kamwi, J. M., Chirwa, P. W. C., Manda, S. O. M., Graz, P. F. (2015): Livelihoods, land use and land cover change in the Zambezi Region, Namibia. - Population and Environment 37(2): 207-230.

[37] Karan, P. P., Lijima, S. (1985): Environmental stress in the Himalaya. - Geographical Review 75: 71-92.

[38] Khan, M. A. (1970): Working Plan of the Upper Kaghan Guzara Forests 1967-68 to 1976-77. - Govt. of West Pakistan, Peshawar.

[39] Khattak, M. S., Babel, M. S., Sharif, M. (2011): Hydro-meteorological trends in the upper Indus river basin in Pakistan. - Climate Research 46: 103-119.

[40] Khurshid, M., Nafees, M., Rahim, I., Rashid, W. (2016): Impacts of agriculture land use changes on mobile pastoral system in Naran valley of Western Himalayan Northern Pakistan. - Sarhad Journal of Agriculture 32(4): 282-288.

[41] Kotzee, I., Reyers, B. (2016): Piloting a social-ecological index for measuring flood resilience: a composite index approach. - Ecological Indicators 60: 45-53.

[42] Kumar, K. V., Martha, T. R., Roy, P. S. (2006): Mapping damage in the Jammu and Kashmir caused by the 8 October $2005 \mathrm{Mw} 7.3$ earthquake from the Cartosat- 1 and Resourcesat-1 imagery. - International Journal of Remote Sensing 27: 4449-4459.

[43] Macchi, M. (2011): Framework for Climate-based Climate Vulnerability and Capacity Assessment in Mountain Areas. - International Centre for Integrated Mountain Development (ICIMOD), Kathmandu, Nepal.

[44] Madhuri, M., Tewari, H. R., Bhowmick, P. K. (2014): Livelihood vulnerability index analysis: An approach to study vulnerability in the context of Bihar. - Jamba Journal of Disaster Risk Studies 6(1): 127-140.

[45] Mahmood, R., Jia, S., Babel, M. S. (2016): Potential impacts of climate change on water resources in the Kunhar River Basin, Pakistan. - Water 8(1): 23. doi: 10.3390/w8010023.

[46] Mona, L. (2014): Seismic hazard assessment of District Mansehra, Khyber Pakhtoonkhawa, Pakistan. - Acta Geologica Sinica 88(4): 1157-1168. 
[47] Munir, M. H., Mirza, K. (2007): Stratigraphic aspect of recent earthquake occurred along the balakot-bagh fault, north-west Himalayas, Pakistan. - Geological Bulletin of Punjab University 42: 25-36.

[48] Panthi, J., Aryal, S., Dahal, P., Bhandari, P., Krakauer, N. Y., Pandey, V. P. (2015): Livelihood vulnerability approach to assessing climate change impacts on mixed agrolivestock smallholders around the Gandaki River Basin in Nepal. - Regional Environmental Change. DOI: 10.1007/s10113-015-0833-y.

[49] Qasim, M., Alam, M., Khan, B., Ahmad, E. (2010): Earthquake induced forest damages in Balakot, Palas Valley, Muzaffarabad and Bagh areas of north west frontier province and Azad Jammu and Kashmir Regions. - World Applied Sciences Journal 8: 912-913.

[50] Rahut, D. B., Ali, A., Kassie, M. P., Marenya, P., Basnet, C. (2014): Rural livelihood diversification strategies in Nepal. - Poverty Public Policy 6(3): 259-281.

[51] Sarwar, F., Iqbal, S., Qaisar, M., Rehman, A., Akhtar, F., Raza, S. M. (2016): Earthquake statistics and earthquake research studies in Pakistan. - Open Journal of Earthquake Research 5: 97-104.

[52] Schickhoff, U. (1995): Himalayan forest-cover changes in historical perspective: A case study in the kaghan valley, northern Pakistan. - Mountain Research and Development 15(1): 3-18.

[53] Shah, A. A., Ye, J., Abid, M., Ullah, R. (2017): Determinants of flood risk mitigation strategies at household level: a case of Khyber districts of Pakhtunkhwa (KP) province, Pakistan. - Natural Hazards 88(1): 415-430.

[54] Shah, A. A., Ye, J., Abid, M., Khan, J., Amir, S. M. (2018): Flood hazards: household vulnerability and resilience in disaster-prone of Khyber Pakhtunkhwa province, Pakistan. - Natural Hazards https://doi.org/10.1007/s11069-018-3293-0.

[55] Shah, K. U., Dulal, H. B., Johnson, C. Baptiste, A. (2013): Understanding livelihood vulnerability to climate change: applying the livelihood vulnerability index in Trinidad and Tobago. - Geoforum 47: 125-137.

[56] Shahzad, L., Tahir, A., Sharif, F. (2018): Understanding the community's perception of climate change and adaptations in the Mid Hills of Pakistan. - Biologia (Pakistan) 64(II): 197-209.

[57] Shahzad, L., Tahir, A., Sharif, A. Haq, I. U., Mukhtar, H. (2019): Assessing the impacts of changing climate on forest ecosystem services and livelihood of Balakot mountainous communities. - Pakistan Journal of Botany 51(4). DOI: http://dx.doi.org/10.30848/PJB2019-4(1).

[58] Sharma, R. K., Sankhayan, P. L., Hofstad, O., Singh, R. (2007): Land use changes in the western Himalayan region - a study at watershed level in the state of Himachal Pradesh, India. - International Journal of Ecology and Environmental Sciences 33(2-3): 197-206.

[59] Soomro, A. S., Rajput, A. Q. K., Solangi, S. H. (2010): The study of change after occurrence of earthquake induced landslide disaster in 2005 in Balakot, Pakistan. Mehran University Research Journal of Engineering \& Technology 31(3): 461-468.

[60] Soomro, A. S., Abbasi, H. U., Memon, A. G., Samo, S. R. (2012): A conceptual model for identifying landslide risk: a case study Balakot, Pakistan. - Sindh University Research Journal 44: 203-208.

[61] Stacy, H. J. (2004): Building connections in qualitative research. Carolyn Ellis and Art Bochner in conversation with Stacy Holman Jones. - Forum Qualitative Sozialforschung/Forum: Qualitative Social Research (On-line Journal) 5(3): Art.28.

[62] Sterling, C., 1976: Nepal. - Atlantic Monthly (Oct) 238(4): 14-25.

[63] Sujakhu, N., Ranjitkar, M., Niraula, S., Asad, R. R., Nizami, A., Schmidt-Vogt, A. D., $\mathrm{Xu}$, J. (2018): Determinants of livelihood vulnerability in farming communities in two sites in the Asian Highlands. - Water International 43(2): 165-182.

[64] Sullivan, C. (2002): Calculating a water poverty index. - World Development 30: 11951210. 
[65] Tse-ring, K., Sharma, E., Chettri, N., Shrestha, A. (2010): Climate Change Vulnerability of Mountain Ecosystems in the Eastern Himalayas-Climate Change Impact and Vulnerability in the Eastern Himalayas. Synthesis Report. - ICIMOD, Kathmandu.

[66] Ullah, R., Shivakoti, G. P., Ali, G. (2015): Factors affecting farmers' risk attitude and risk perceptions: The case of Khyber Pakhtunkhwa, Pakistan. - International Journal of Disaster Risk Reduction 13: 151-157.

[67] Ullah, W., Takaaki, N., Muhammad, N., Rahman, Z., Muhammad, A. (2017): Understanding climate change vulnerability, adaptation and risk perceptions at household level in Khyber Pakhtunkhwa, Pakistan. - International Journal of Climate Change Strategies and Management. doi.org/10.1108/IJCCSM-02-2017-0038.

[68] UNDP (2007): Building Enabling Governance and Institutions for Earthquake Response (BEGIN-ER): Mansehra District Disaster Risk Management Plan. - United Nations Development Programme, Govt. of Pakistan.

[69] Wang, Y. R., Zhao, X. Y., Zhang, Q., Luo, L. (2016): Farmers' climate change adaptation strategies in an ecologically vulnerable alpine region: a case of Gannan Plateau. Geographical Research 37: 2392-2402.

[70] World Bank (1979): Nepal: Development Performance and Prospects - A World Bank Country Study. - South Asia Regional Office, World Bank, Washington, DC.

[71] WWF (2017): Third Party Monitoring of Billion Trees Afforestation Project in Khyber Pakhtunkhwa. - WWF, Pakistan.

[72] Yang, W., Yang. Z. F. (2014): Evaluation of sustainable environmental flows based on the valuation of ecosystem services: a case study for the Baiyangdian Wetland, China. Journal of Environmental Informatics 24: 90-100.

[73] Yohannes, A. W., Cotter, M., Kelboro, G., Dessalegn, W. (2018): Land use and land cover changes and their effects on the landscape of Abaya-Chamo Basin, Southern Ethiopia. - Land 7: 2.

[74] Zaheer, K., Colom, A. (2013): Pakistan - How the People of India live with Climate Change and what Communication Can Do. - BBC Media Action, London, UK.

[75] Zhang, Q., Xueyan, Z., Haiping, T. (2018): Vulnerability of communities to climate change - application of the livelihood vulnerability index to an environmentally sensitive region of China. - Climate and Development https://doi.org/10.1080/17565529.2018.1442808.

\section{APPENDIX}

Table A1. Summary of LVI scores for UC Kawai and UC Balakot

\begin{tabular}{|c|c|c|c|c|c|c|c|c|c|}
\hline \multirow{2}{*}{$\begin{array}{l}\text { Vulnerability } \\
\text { components }\end{array}$} & \multirow{2}{*}{$\begin{array}{c}\text { Major } \\
\text { components }\end{array}$} & \multirow{2}{*}{$\begin{array}{c}\text { Indicators } \\
\text { (questions inquired) }\end{array}$} & \multirow[b]{2}{*}{ Units } & \multicolumn{2}{|c|}{ BALAKOT } & \multicolumn{2}{|c|}{ KAWAI } & \multirow{2}{*}{$\begin{array}{l}\text { Max. } \\
\text { value }\end{array}$} & \multirow{2}{*}{$\begin{array}{l}\text { Min. } \\
\text { value }\end{array}$} \\
\hline & & & & $\begin{array}{l}\text { Actual } \\
\text { value }\end{array}$ & \begin{tabular}{|c|}
$\begin{array}{c}\text { Standardized } \\
\text { value }\end{array}$ \\
\end{tabular} & $\begin{array}{l}\text { Actual } \\
\text { value }\end{array}$ & $\begin{array}{c}\text { Standardized } \\
\text { value }\end{array}$ & & \\
\hline \multirow[t]{5}{*}{ Exposure } & \multirow{4}{*}{$\begin{array}{l}\text { Natural } \\
\text { disasters }\end{array}$} & $\begin{array}{c}\text { Number of hazards/natural } \\
\text { disasters faced in the last } 5 \\
\text { years }\end{array}$ & $\begin{array}{c}\text { Range/count } \\
(0-5)\end{array}$ & 4.4 & 0.8 & 2.8 & 0.27 & 5 & 2 \\
\hline & & $\begin{array}{c}\text { Family members did not get } \\
\text { any warning of natural } \\
\text { disasters }\end{array}$ & Percentage & 100 & 1 & 100 & 1.00 & 100 & 0 \\
\hline & & $\begin{array}{c}\text { Death/Injury in your } \\
\text { household due to natural } \\
\text { disaster }\end{array}$ & Percentage & 52.5 & 0.525 & 24.5 & 0.25 & 100 & 0 \\
\hline & & $\begin{array}{l}\text { Damage to physical } \\
\text { properties and loss of } \\
\text { agriculture land as a } \\
\text { consequence of natural } \\
\text { disasters }\end{array}$ & Percentage & 77.5 & 0.775 & 56.7 & 0.57 & 100 & 0 \\
\hline & & & & & 0.78 & & 0.52 & & \\
\hline
\end{tabular}


Shahzad et al.: Does livelihood vulnerability index justify the socio-economic status of mountainous community? A case study of post-earthquake ecological adaptation of Balakot population

$$
-6623-
$$

\begin{tabular}{|c|c|c|c|c|c|c|c|c|c|}
\hline & \multirow{3}{*}{$\begin{array}{c}\text { Climate } \\
\text { variability }\end{array}$} & $\begin{array}{l}\text { Mean standard deviation of } \\
\text { monthly average of average } \\
\text { maximum daily temperature }\end{array}$ & Celsius & 12.8 & 0.052 & 12.8 & 0.052 & 34.7 & 11.6 \\
\hline & & $\begin{array}{l}\text { Mean standard deviation of } \\
\text { monthly average of average } \\
\text { minimum daily temperature }\end{array}$ & Celsius & 6.9 & 0.197 & 6.9 & 0.197 & 20.8 & 3.5 \\
\hline & & $\begin{array}{c}\text { Mean standard deviation of } \\
\text { monthly average } \\
\text { precipitation }\end{array}$ & $\mathrm{mm}$ & 116 & 0.266 & 116 & 0.266 & 324.4 & 40.3 \\
\hline & & & & & 0.172 & & 0.172 & & \\
\hline \multirow{18}{*}{ Sensitivity } & \multirow{6}{*}{ Health } & $\begin{array}{c}\text { Average time to reach basic } \\
\text { health facility }\end{array}$ & Min & 20.5 & 0.24 & 33.6 & 0.44 & 70 & 5 \\
\hline & & $\begin{array}{c}\begin{array}{c}\text { Affordability of basic health } \\
\text { services }\end{array} \\
\end{array}$ & Percentage & 32 & 0.32 & 29.5 & 0.30 & 100 & 0 \\
\hline & & $\begin{array}{c}\text { Household with chronic ill } \\
\text { members }\end{array}$ & Percentage & 22 & 0.22 & 18 & 0.18 & 100 & 0 \\
\hline & & \begin{tabular}{|c|} 
Household members \\
missing school or work due \\
to illness (in last 2 weeks)
\end{tabular} & Percentage & 11 & 0.11 & 9 & 0.09 & 100 & 0 \\
\hline & & $\begin{array}{c}\text { Household having toilet in } \\
\text { use }\end{array}$ & Percentage & 83.5 & 0.84 & 77.8 & 0.78 & 100 & 0 \\
\hline & & Household using wood & Percentage & 98.6 & 0.99 & 95.4 & 0.95 & 100 & 0 \\
\hline & & & & & 0.45 & & 0.46 & & \\
\hline & \multirow{5}{*}{ Food } & $\begin{array}{c}\text { Food sufficiency (household } \\
\text { has food storage for six } \\
\text { month) }\end{array}$ & Percentage & 24.4 & 0.24 & 39.2 & 0.39 & 100 & 0 \\
\hline & & Average crop diversity & $\begin{array}{l}1 / \text { no.of } \\
\text { crops }\end{array}$ & 0.18 & 0.29 & 0.21 & 0.36 & 0.5 & 0.05 \\
\hline & & $\begin{array}{l}\text { Housing dependency on } \\
\text { fishing/hunting for food }\end{array}$ & Percentage & 39.5 & 0.40 & 35.6 & 0.36 & 100 & 0 \\
\hline & & $\begin{array}{c}\text { Household primarily } \\
\text { dependent on self-farmed } \\
\text { food }\end{array}$ & Percentage & 22.5 & 0.23 & 34.4 & 0.34 & 100 & 0 \\
\hline & & Household saving seeds & Percentage & 6.8 & 0.07 & 23.5 & 0.24 & 100 & 0 \\
\hline & & & & & 0.24 & & 0.34 & & \\
\hline & \multirow{5}{*}{ Water } & $\begin{array}{l}\text { Dependency of household } \\
\text { on natural water sources }\end{array}$ & Percentage & 42 & 0.42 & 66 & 0.66 & 100 & 0 \\
\hline & & $\begin{array}{l}\text { Average days without a } \\
\text { water supply per month }\end{array}$ & Days & 8.55 & 0.71 & 6.71 & 0.34 & 10 & 5 \\
\hline & & $\begin{array}{c}\text { Household without pipe } \\
\text { borne water }\end{array}$ & Percentage & 49 & 0.49 & 55 & 0.55 & 100 & 0 \\
\hline & & $\begin{array}{l}\text { Consistency of drinking } \\
\text { water supply }\end{array}$ & Percentage & 32 & 0.32 & 25 & 0.25 & 100 & 0 \\
\hline & & & & & 0.49 & & 0.45 & & \\
\hline \multirow[t]{10}{*}{$\begin{array}{l}\text { Adaptive } \\
\text { capacity }\end{array}$} & \multirow{5}{*}{ Socio-demo } & $\begin{array}{l}\text { Dependency ratio per } \\
\text { household }\end{array}$ & Ratio & 2.44 & 0.44 & 1.56 & 0.25 & 5 & 0.4 \\
\hline & & $\begin{array}{l}\text { Households with a head } \\
\text { who is a female }\end{array}$ & Percentage & 26 & 0.26 & 18 & 0.18 & 100 & 0 \\
\hline & & \begin{tabular}{|c|}
$\begin{array}{c}\text { Households having access to } \\
\text { radio, telephone or } \\
\text { television }\end{array}$ \\
\end{tabular} & Percentage & 66 & 0.66 & 48 & 0.48 & 100 & 0 \\
\hline & & $\begin{array}{l}\text { Head of household never } \\
\text { joined any school/college } \\
\text { etc. }\end{array}$ & Percentage & 23 & 0.23 & 19 & 0.19 & 100 & 0 \\
\hline & & & & & 0.40 & & 0.28 & & \\
\hline & \multirow[t]{5}{*}{$\begin{array}{l}\text { Livelihood } \\
\text { strategies }\end{array}$} & $\begin{array}{l}\text { Any member of household } \\
\text { working outside the Tehsil } \\
\text { for spontaneous work }\end{array}$ & Percentage & 54 & 0.54 & 41 & 0.41 & 100 & 0 \\
\hline & & $\begin{array}{c}\text { Any family member } \\
\text { involved in local tourism for } \\
\text { their livelihood }\end{array}$ & Percentage & 22 & 0.22 & 4 & 0.04 & 100 & 0 \\
\hline & & \begin{tabular}{|c|}
$\begin{array}{c}\text { Household's dependence } \\
\text { upon fishing and hunting for } \\
\text { their day to day life }\end{array}$ \\
\end{tabular} & Percentage & 21 & 0.21 & 16 & 0.16 & 100 & 0 \\
\hline & & $\begin{array}{c}\text { Crop cultivation as a main } \\
\text { source of income }\end{array}$ & Percentage & 48 & 0.48 & 54 & 0.54 & 100 & 0 \\
\hline & & $\begin{array}{c}\text { Agricultural livelihood } \\
\text { diversification in a } \\
\text { household }\end{array}$ & $\begin{array}{c}\text { 1/no.of } \\
\text { livelihoods }\end{array}$ & 0.24 & 0.00 & 0.22 & 0.00 & 100 & 0 \\
\hline
\end{tabular}


Shahzad et al.: Does livelihood vulnerability index justify the socio-economic status of mountainous community? A case study of post-earthquake ecological adaptation of Balakot population

-6624 -

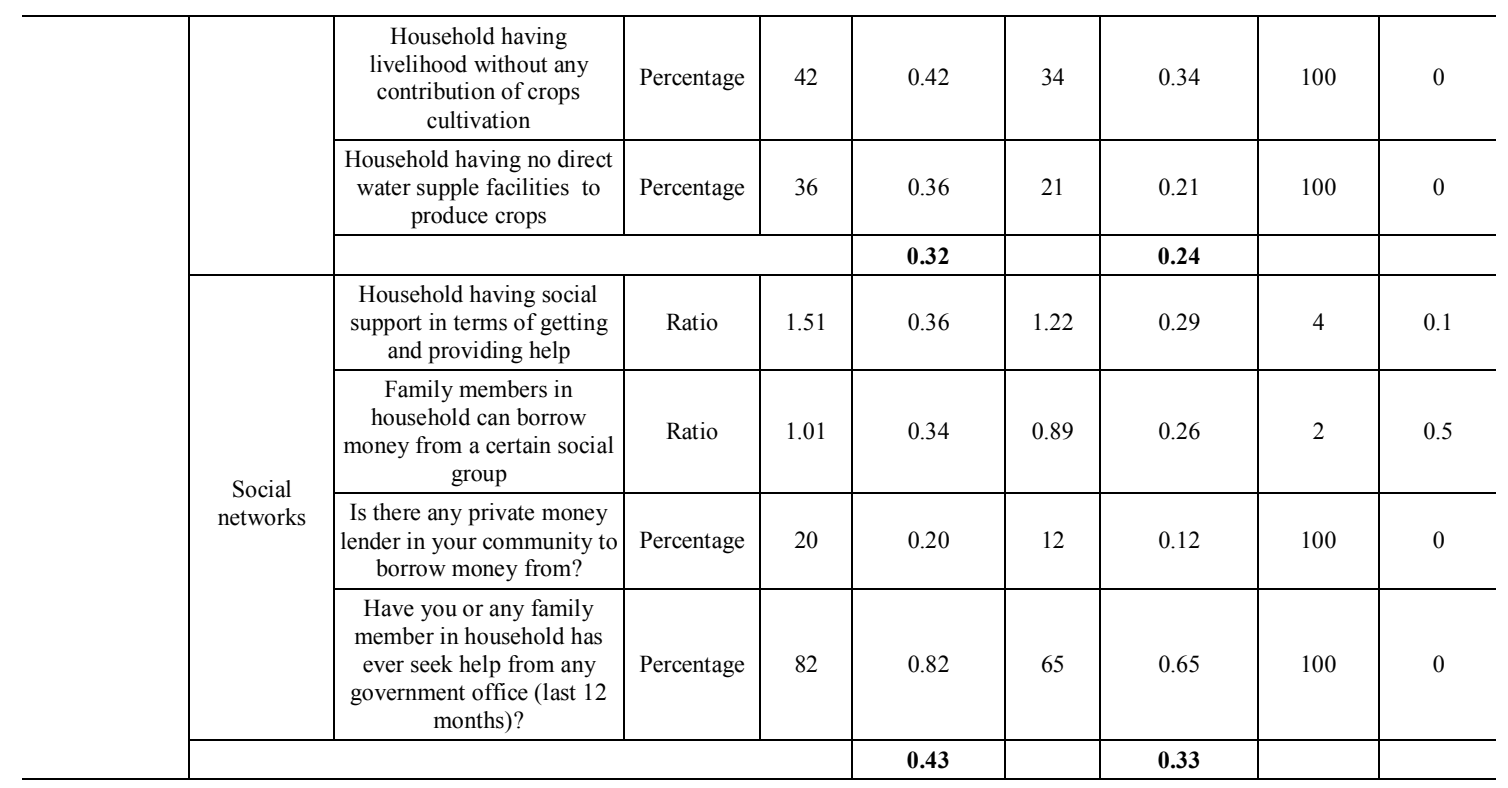

